\title{
Screening of Antibacterial Activities of the Endophytic Fungi Isolated from the Leaves of Medinilla speciosa Blume
}

\author{
Puteri Amelia $^{1^{*},}$ Rachma Ayunda ${ }^{1}$, Saiful Bahri ${ }^{2}$ \\ ${ }^{1}$ Department of Pharmacy, Faculty of Health Sciences, Universitas Islam Negeri Syarif Hidayatullah \\ Jakarta, Indonesia \\ ${ }^{2}$ Department of Pharmacy, Faculty of Pharmacy, National Institute of Science and Technology \\ Jakarta, Indonesia
}

\begin{tabular}{|c|c|}
\hline Article info & Abstract \\
\hline History & Endophytes or endophytic fungi have been investigated as a storehouse of \\
\hline Submission: $15-11-2020$ & bioactive compounds. This study was aimed to evaluate the potential \\
\hline Review: $29-12-2020$ & antibacterial activity of endophytic fungi isolated from the leaves of \\
\hline Accepted: $24-02-2021$ & Medinilla speciosa Blume. The antibacterial test was determined by \\
\hline $\begin{array}{l}\text { *Email: } \\
\text { puteri.amelia@uinjkt.ac.id }\end{array}$ & $\begin{array}{l}\text { measuring the inhibition zone with disk-diffusion method. Twenty } \\
\text { endophytes were isolated from the leaves of Medinilla speciosa Blume and } \\
\text { identified morphologically. The results demonstrated that ten isolates }\end{array}$ \\
\hline DOI: $10.33096 /$ jffi.v8i3.729 & $\begin{array}{l}\text { showed variation in their antibacterial activity against Escherichia coli } \\
\text { ATCC } 25922 \text {, Staphylococcus aureus ATCC } 25923 \text {, Bacillus subtilis ATCC }\end{array}$ \\
\hline $\begin{array}{l}\text { Keywords: } \\
\text { Medinilla speciosa Blume; } \\
\text { endophytic fungi; antibacterial } \\
\text { activity; disk-diffusion method }\end{array}$ & $\begin{array}{l}\text { 6633, and Shigella dysenteriae ATCC 13313. Further investigation will be } \\
\text { needed to explore and identify the bioactive molecules of the isolated } \\
\text { endophytic fungi. }\end{array}$ \\
\hline
\end{tabular}

\section{Introduction}

The discoveries of natural bioactive compounds and their therapeutic properties have been investigated since the emergence of new diseases and drug-resistant problems. In recent years, the research to develop a new and safe drugs from natural resources is explored extensively. The bioactive compounds can be lead from many sources; plants, animals, marine organisms, and endophytic microbes (Christina, Christapher and Bhore, 2013).

Plants are known as a reservoir of endophytes, including fungi, bacteria, and actinomycetes (Strobel et al., 2004). The ability of endophytic microbes to produce bioactive compounds has been widely investigated since the discovery of penicillin from Penicillium notatum by Alexander Fleming in 1928 (Akanksha, Bhardwaj and Agrawal, 2014). Endophytic are microorganism which grown in living tissues of higher plants, establishing mutual relationship without causing any apparent symptoms and negative effect on their host.

It has been known that endophytic fungi are an important source of bioactive compounds. Up to now, the production of endophytes metabolites as antibacterial, antifungal, antidiabetic, anticancer, antiviral activities, and other pharmacological activities has been increasingly investigated (Gouda et al., 2016). Using endophytic microbes as a source of raw material for developing new drugs from the herbal plant was very beneficial advantageous because it can be obtained without killing the host plant, hence environmental sustainability can be preserved (Kumala, DwiYuliani and Simanjuntak, 2015).

One of Indonesian plant species which has not been fully explored in terms of pharmacology is Medinilla. Medinilla speciosa Blume is distributed in Indonesia, Malaysia, and the Philippines. Traditionally, the fruit of this plant has been consumed by pregnant women and also used as medicine for diarrhea, mouth sores, inflammatory, cancer, and bacterial infection (Hanum, Prihastanti and Jumari, 2017). In order to searching for more bioactive endophytic fungi of this plant, the isolation and antibacterial screening from the leaves was carried out. Herein are reported the endophytic isolates and their antibacterial activities against Escherichia coli, Staphylococcus aureus, Bacillus subtilis, and Shigella dysenteriae.

\section{Research Method \\ II.1 Sample Preparation}

The leaves of Medinilla speciosa Blume were collected from Mount Muria in Kudus Regency, Central Java, Indonesia in May 2015. Authentication and identification of plant were carried out at Centre for Plant Conservation Botanic Gardens, Bogor, Indonesia.

\section{II.2 Isolation and Purification of Endophytic Fungi}

Fresh leaves of $M$. speciosa Blume were washed in running tap water for $10 \mathrm{~min}$ to remove the dust and transferred to aseptic condition. The 
selected leaves then immersed $95 \%$ ethanol for 30 sec, $4 \%$ sodium hypochlorite solution for $3 \mathrm{~min}$, and $95 \%$ ethanol for $30 \mathrm{sec}$ followed by rinsing with sterile distilled water three times. After drying, they were cut into small approximately $0.5 \mathrm{~cm}$ and placed on potato dextrose agar medium (PDA) supplemented with streptomycin $(100 \mu \mathrm{g} / \mathrm{ml})$ to suppress bacterial growth. The agar plates were incubated at $25 \pm 2{ }^{\circ} \mathrm{C}$ for a maximum of 21 days for fungal growth (Bhardwaj et al., 2015).

\section{II.3 Screening of Antibacterial Activity of Isolated Endophytic fungi}

The screening of antibacterial activity of the isolated endophytic fungi was carried out by using the agar well diffusion method (Balouiri, Sadiki and Ibnsouda, 2016) with four pathogenic bacterial strains: Escherichia coli ATCC 25922, Staphylococcus aureus ATCC 25923, Bacillus subtilis ATCC 6633, and Shigella dysenteriae ATCC 13313. A sterile cork borer of $6 \mathrm{~mm}$ was used to cut the portion of mycelia mat of the isolates and transferred to pre-sterile nutrient agar medium plates contains bacterial test suspension. The clear zone around the isolates demonstrated microbe inhibition zone area and was measured in millimeter $(\mathrm{mm})$ scale.

\section{II.4 Morphological Characteristic of Isolated Endophytic Fungi \\ The morphological identification of} isolated endophytic fungi was performed by microscopic identification and macroscopic morphological characterization, including the color of the colonies, the exudate drops, zonation, also the types of hyphae, and mycelium (Alsohaili and BaniHasan, 2018).

\section{II.5 Fermentation of Isolated Endophytic Fungi}

Pure endophytic isolates were transferred to freshly prepared PDA to establish stock cultures and incubated $25 \pm 2{ }^{\circ} \mathrm{C}$ for 6-7 days. Three pieces of inoculum were selected with a sterile cork borer of diameter $6 \mathrm{~mm}$ and transferred into $200 \mathrm{ml}$ presterile liquid fermentation media potato dextrose yeast (PDY). This was further fermented for the next 14 days at $25 \pm 2{ }^{\circ} \mathrm{C}$. The supernatant was separated from biomass via centrifugation at $3000 \mathrm{rpm}$ for 15 min and refiltered for the estimation of antibacterial activity (Aharwal et al., 2018).

\section{II.6 Antibacterial Activity Test}

All the bacterial tests were inoculated into the nutrient broth (NB) media and incubated at 35 ${ }^{\circ} \mathrm{C}-37{ }^{\circ} \mathrm{C}$ for $18-24$ hours. Each of these bacterial suspensions was compared to McFarland standard 0.5 (1.5 x $108 \mathrm{CFU} / \mathrm{ml})$ (Techaoei et al., 2020) for density uniformity and then $100 \mu \mathrm{l}$ of the bacterial suspension was spread onto nutrient agar (NA) using a sterile cotton bud in a Petri dish until all surface was covered. Then, a filter paper discs (about $6 \mathrm{~mm}$ in diameter), containing $20 \mu \mathrm{l}$ of the test compound are placed on the agar surface. The discs were incubated at $35{ }^{\circ} \mathrm{C}-37{ }^{\circ} \mathrm{C}$ for $18-24$ hours. The sensitivities of the microorganism against the fungal isolates were determined by measuring the diameter of inhibitory zones compared to chloramphenicol as a positive control and aquadest as a negative control (Balouiri, Sadiki and Ibnsouda, 2016).

\section{Results and Discussion}

Totally, 20 endophytic fungi isolates were successfully obtained from the leaves of M. speciosa Blume collected from Central Java, Indonesia. Fermentation of endophytic fungi was done by using PDY medium because it contains rich carbon sources from potato extracts and dextrose, also nitrogen source from its yeast extract. The fermentation process was performed at room temperature under static conditions (Kumala, DwiYuliani and Simanjuntak, 2015).

All fungal isolates were screened for their antibacterial activity against bacterial test Grampositive bacteria (S. aureus, B. subtilis) and Gramnegative bacteria ( $E$. coli, $S$. dysenteriae). Chloramphenicol was chosen as a positive control because it has a wide spectrum against Grampositive bacteria and Gram-negative bacteria and it is also known as a bacteriostatic agent (Jayatilake and Munasinghe, 2020). Out of twenty, ten endophytic isolates were selected based on their ability to inhibit the growth of bacterial tests as shown in Table 1.

Table 1. Screening of isolated endophytic fungi against four pathogenic bacteria

\begin{tabular}{lllll}
\hline \multirow{2}{*}{$\begin{array}{l}\text { Fungal } \\
\text { Isolates }\end{array}$} & \multicolumn{4}{l}{ Zone of inhibition $(\mathbf{m m})$} \\
\cline { 2 - 5 } & S. aureus & B. subtilis & E. coli & S.dysenteriae \\
\hline DPU1 (a) & 9.71 & - & - & - \\
DPU3 (b) & 12.4 & 7.00 & - & - \\
DPU4 (c) & - & 8.70 & 20.13 & - \\
DTE1 (d) & 9.65 & - & 10.66 & - \\
DTE3 (e) & 11.67 & - & 11.06 & - \\
DTU1 (f) & 9.10 & - & 16.32 & - \\
DTU4 (g) & - & 7.22 & 10.55 & 6.90 \\
\hline
\end{tabular}




\begin{tabular}{lllll}
\hline DTU6 (h) & - & 6.42 & - & 7.05 \\
DTU7 (i) & - & 6.75 & 12.35 & 6.92 \\
DTU9 (j) & - & 6.72 & 9.75 & - \\
Positive Control & 20.21 & 15.32 & 13.63 & 15.52 \\
Negative Control & & & & \\
\hline
\end{tabular}

After screening the antibacterial activity of the endophytic fungi isolates, ten selected isolates were further identified based on their macroscopic and microscopic characteristic (Figure 1). The morphological identification of endophytic fungal strains is based on the morphology of the fungal culture colony or hyphae (Ma et al., 2018), the characteristics of the spores (Sudirga, 2016), and reproductive structures (Mbilu et al., 2018). Based on their cultural and microscopic properties (Navi et al., 1999), these fungi show different characteristics and successfully identified as described in Table 2.

Table 2. Phenotypic characteristics of isolated endophytic fungi from the leaves of $M$. speciosa Blume

\begin{tabular}{|c|c|c|c|}
\hline $\begin{array}{l}\text { Fungal } \\
\text { Isolate }\end{array}$ & Macroscopic Characteristic & Microscopic Characteristic & $\begin{array}{l}\text { Probable } \\
\text { Genera/Species }\end{array}$ \\
\hline DPU1 (a) & $\begin{array}{l}\text { Colonies were powder in texture } \\
\text { and black with conidial production }\end{array}$ & $\begin{array}{l}\text { Hyphae septate hyaline } \\
\text { dichotomously branched vesicle, } \\
\text { round, radiate head, black conidia. }\end{array}$ & Alternaria sp. \\
\hline DPU3 (b) & $\begin{array}{l}\text { The surface of the colony is white } \\
\text { orange; the color is white orange in } \\
\text { reverse. }\end{array}$ & $\begin{array}{l}\text { Multi-celled spores, conidia are } \\
\text { oval-shaped and attached to } \\
\text { conidiophores arise from a septate } \\
\text { mycelium. }\end{array}$ & Colletotrichum sp. \\
\hline DPU4 (c) & $\begin{array}{l}\text { Colony surface greenish-white, } \\
\text { greenish-yellow inverted color, } \\
\text { thick hyphal texture. }\end{array}$ & $\begin{array}{l}\text { Conidiophores arising from a } \\
\text { septate mycelium. }\end{array}$ & Penicillium sp. \\
\hline DTE1 (d) & $\begin{array}{l}\text { The surface of the colony is } \\
\text { brownish-white, the reverse color } \\
\text { is brownish-green white. }\end{array}$ & $\begin{array}{l}\text { Hyphae septate and branched, } \\
\text { conidia which form a brownish- } \\
\text { yellow chain }\end{array}$ & Aspergillus sp. \\
\hline DTE3 (e) & $\begin{array}{l}\text { The surface of the colony is white } \\
\text { brownish-yellow, the color is a } \\
\text { brownish-yellow reversal, forming } \\
\text { concentric circles }\end{array}$ & $\begin{array}{l}\text { Hyphae septate and branched, } \\
\text { having conidia and } \\
\text { chlamydospores that appear on the } \\
\text { septate mycelium. }\end{array}$ & Humicola sp. \\
\hline DTU1 (f) & $\begin{array}{l}\text { The surface of the colony is } \\
\text { brownish-white, the color is } \\
\text { brownish-yellow in reverse }\end{array}$ & $\begin{array}{l}\text { Hyphae septate and branched, } \\
\text { conidiophores arise from a septate } \\
\text { mycelium. }\end{array}$ & Corynespora sp. \\
\hline DTU4 (g) & Colony like cotton is white and flat & $\begin{array}{l}\text { Hyphae septate and branched and } \\
\text { the colony has spores that are oval } \\
\text { rod-like in shape. }\end{array}$ & Trichophyton sp. \\
\hline DTU6 (h) & $\begin{array}{l}\text { Upper colonies are hyaline to dark } \\
\text { then turn brownish-gray, in } \\
\text { contrast to brownish color. }\end{array}$ & $\begin{array}{l}\text { Hyphae septate and branched, } \\
\text { conidia obovoid. }\end{array}$ & Botrytis sp. \\
\hline DTU7 (i) & Colony like cotton is white and flat & $\begin{array}{l}\text { Hyphae septate and branched and } \\
\text { the colony has spores that are oval } \\
\text { rod-like in shape. }\end{array}$ & Trichophyton sp. \\
\hline DTU9 (j) & $\begin{array}{l}\text { The surface of the colony is } \\
\text { uneven and stringy like cotton, the } \\
\text { color of the surface is grayish- } \\
\text { white and the color is creamy with } \\
\text { black circles. }\end{array}$ & $\begin{array}{l}\text { Hyphae septate and branched, } \\
\text { conidiophores arise from a septate } \\
\text { mycelium. }\end{array}$ & Phomopsis sp. \\
\hline
\end{tabular}



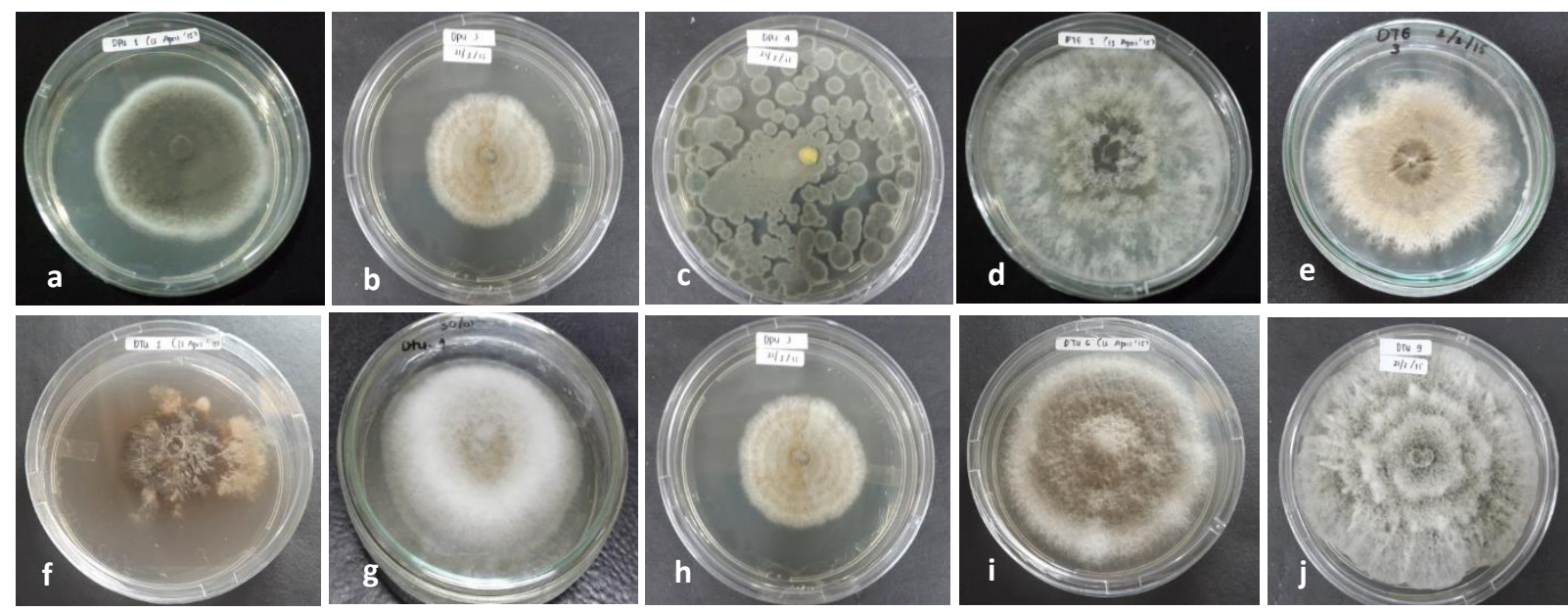

Figure 1. Endophytic Fungi Isolates

Note; (a)=DPU1; (b)=DPU3; (c)=DPU4; (d)=DTE1; (e)=DTE3; (f)=DTU1; (g)=DTU4; (h)=DTU6; (i)=DTU7; (j)=DTU9

The antimicrobial activities of the endophytic microbes, primary was determined by measuring the inhibition zone with the diskdiffusion method. The test microorganisms were chosen due to their pathogenicity. The bacterial growth curve was studied to determine the growth rate of the bacteria. The chloramphenicol was used as a positive control and aquadest was used as a negative control.
The result of antibacterial activity of the endophytic fungi fermentation showed that DPU1, DPU3, DPU4, DTE1, DTU1, DTU7, and DTU9 were active against $S$. aureus ATCC 25923; DPU3, DPU4, DTE1, DTU1, DTU4, and DTU6 were active against B. subtilis ATCC 6633; all isolates were actives against $E$. coli ATCC 25922, and all isolates were active against $S$. dysenteriae ATCC 13313 except for DTU7 (Table. 3).

Table. 3. Zone of inhibition of potent endophytic fungi isolates

\begin{tabular}{lllll}
\hline \multirow{2}{*}{$\begin{array}{l}\text { Fungal } \\
\text { Isolates }\end{array}$} & \multicolumn{4}{l}{ Zone of inhibition $(\mathbf{m m})$} \\
\cline { 2 - 5 } & S.aureus & B.subtilis & E.coli & S.dysenteriae \\
\hline DPU1 (a) & 7.85 & - & 6.42 & 6.68 \\
DPU3 (b) & 7.53 & 6.21 & 6.38 & 6.46 \\
DPU4 (c) & 7.78 & 6.11 & 6.26 & 6.68 \\
DTE1 (d) & 6.96 & 7.05 & 6.91 & 7.31 \\
DTE3 (e) & - & - & 7.03 & 6.11 \\
DTU1 (f) & 6.95 & 7.21 & 7.28 & 6.71 \\
DTU4 (g) & - & 5.76 & 6.86 & 6.11 \\
DTU6 (h) & - & 7.03 & 6.35 & 7.68 \\
DTU7 (i) & 6.55 & - & 6.91 & - \\
DTU9 (j) & 6.61 & - & 6.91 & 5.92 \\
\hline Positive Control & 19.46 & 14.52 & 10.94 & 16.91 \\
Negative Control & - & - & - & - \\
\hline
\end{tabular}

\section{Conclusions}

Twenty endophytic fungi isolates were successfully obtained from the leaves of $M$. speciosa Blume. Ten of the isolates have shown the variation of inhibiting zone against the bacterial test. The study revealed the presence of good antibacterial activity for the isolates DPU3, DPU4, DTE1, and DTU1. These isolates could be a good source for bioactive compounds and the secondary metabolites compounds may be further isolated.

\section{References}

Aharwal, R. P. et al. (2018) 'Evaluation of Antibacterial Activity of Endophytic Fungi
Aspergillus japonicus Isolated From Tridax procumbens L.', Asian Journal of Pharmaceutical and Clinical Research, 11(9), $\quad$ p. $212 . \quad$ doi: 10.22159/ajpcr.2018.v11i9.21564.

Akanksha, B., Bhardwaj, A. and Agrawal, P. (2014) 'A Review Fungal Endophytes: As a Store House of Bioactive Compound.', World Journal of Pharmacy and Pharmaceutical Sciences, 3(9), pp. 228-237.

Alsohaili, S. A. and Bani-Hasan, B. M. (2018) 'Morphological and Molecular Identification of Fungi Isolated from Different Environmental Sources in the 
Northern Eastern Desert of Jordan', Jordan Journal of Biological Sciences, 11(3), pp. 329-337.

Balouiri, M., Sadiki, M. and Ibnsouda, S. K. (2016) 'Methods for in vitro evaluating antimicrobial activity: A review', Journal of Pharmaceutical Analysis, 6(2), pp. 7179. doi: 10.1016/j.jpha.2015.11.005.

Bhardwaj, A. et al. (2015) 'Antimicrobial and Phytochemical Screening of Endophytic Fungi Isolated from Spikes of Pinus roxburghii', Archives of Clinical Microbiology, 6(3), pp. 1-9.

Christina, A., Christapher, V. and Bhore, S. (2013) 'Endophytic Bacteria as a Source of Novel Antibiotics: An Overview', Pharmacognosy Reviews, 7(13), pp. 11-16. doi: 10.4103/0973-7847.112833.

Gouda, S. et al. (2016) 'Endophytes: A Treasure House of Bioactive Compounds of Medicinal Importance', Frontiers in Microbiology, 7(SEP). doi: 10.3389/fmicb.2016.01538.

Hanum, A. S., Prihastanti, E. and Jumari (2017) 'Ethnobotany of Utilization, Role, and Philosopical Meaning of Parijoto (Medinilla, spp) on Mount Muria in Kudus Regency, Central Java', AIP Conference Proceedings, 1868(2017). doi: 10.1063/1.4995210.

Jayatilake, P. L. and Munasinghe, H. (2020) 'Antimicrobial Activity of Cultivable Endophytic and Rhizosphere Fungi Associated with "mile-a-Minute," Mikania cordata (Asteraceae)', BioMed Research International, 2020. doi: 10.1155/2020/5292571.

Kumala, S., DwiYuliani, K. and Simanjuntak, P. (2015) 'Antimicrobial Activity of Secondary Metabolites Produced by Endophytic Fungi Isolated from Stems of Jati tree (Tectonagrandis L.F)', International Journal of Pharmaceutical Sciences and Research, 6(6), pp. 23492353. doi: 10.13040/IJPSR.09758232.6(6).2349-53.

Ma, D. et al. (2018) 'Evaluation of Bioactivity and Control Efficacy of Tetramycin Against Corynespora cassiicola', Pesticide Biochemistry and Physiology, 152, pp. 106-113. doi: 10.1016/j.pestbp.2018.09.009.

Mbilu, M. et al. (2018) 'Isolation and Characterization of Endophytic Fungi from Medicinal Plant Warburgia ugandensis', 8(12), pp. 57-66.

Navi, S. S. et al. (1999) A Pictorial Guide for the Identification of Mold Fungi on Sorghum Grain Hall, International Crops Research Institute for Semi Arid Tropics, 1999.
Strobel, G. et al. (2004) 'Natural Products from Endophytic Microorganisms', Journal of Natural Products, 67(2), pp. 257-268. doi: 10.1021/np030397v.

Sudirga, S. K. (2016) 'Isolasi dan Identifikasi Jamur Colletotrichum Spp. Isolat Pcs Penyebab Penyakit Antraknosa Pada Buah Cabai Besar (Capsicum Annuum L.) di Bali', Metamorfosa: Journal of Biological Sciences, 3(1), pp. 23-30. doi: 10.24843/Metamorfosa.2016.v03.i01.p04.

Techaoei, S. et al. (2020) 'Chemical Evaluation And Antibacterial Activity Of Novel Bioactive Compounds From Endophytic Fungi in Nelumbo nucifera', Saudi Journal of Biological Sciences, 27(11), pp. 28832889. doi: 10.1016/j.sjbs.2020.08.037. 